Article

\title{
Success Factors for the Foundation of Municipal Utilities in Germany
}

\author{
Oliver Wagner ${ }^{1, *\left(\mathbb{C}, \text { Kurt Berlo }^{1}, \text { Christian Herr }^{2} \text { and Michael Companie }\right.}{ }^{3}$ \\ 1 Research Group Energy, Transport and Climate Policy, Wuppertal Institute, 42103 Wuppertal, Germany; \\ kurt.berlo@wupperinst.org \\ 2 Managing Director of the Municipal Office for Waste Disposal, Street Cleaning and Vehicle Fleet in \\ Regensburg, 93053 Regensburg, Germany; herr.christian@regensburg.de \\ 3 Manager at Plenum AG BLUBERRIES GmbH, 81541 Munich, Germany; \\ michael.companie@plenum-bluberries.de \\ * Correspondence: oliver.wagner@wupperinst.org; Tel.: +49-202-2492-188
}

Citation: Wagner, O.; Berlo, K.; Herr, C.; Companie, M. Success Factors for the Foundation of Municipal Utilities in Germany. Energies 2021, 14, 981. https://doi.org/10.3390/en14040981

Academic Editor:

Ruud Egging-Bratseth

Received: 15 January 2021

Accepted: 10 February 2021

Published: 13 February 2021

Publisher's Note: MDPI stays neutral with regard to jurisdictional claims in published maps and institutional affiliations.

Copyright: (c) 2021 by the authors. Licensee MDPI, Basel, Switzerland. This article is an open access article distributed under the terms and conditions of the Creative Commons Attribution (CC BY) license (https:// creativecommons.org/licenses/by/ $4.0 /)$.

\begin{abstract}
More than 150 municipal utilities (so-called Stadtwerke) were established in Germany from the beginning of the millennium, bringing the total number of Stadtwerke currently established within the country to approximately 900 . With responsibility for more than half of the supply of electricity, gas and heat in Germany, these Stadtwerke play a central role in the transformation of the energy sector, or Energiewende. In addition, due to their local and regional ties, Stadtwerke have a particular role to play in energy politics, the economy and across society. This article focuses on the motives behind, and grounds for, the current wave of newly established Stadtwerke. Further, it discusses the factors that were critical to the successful formation of new Stadtwerke in recent years. The results of our survey indicate that the establishment of municipal Stadtwerke is a suitable measure to implement the energy transition at the local level, whereby the concept of public value has a high level of importance for the local decision-makers. Collaboration and cooperation, as well as a resilience-oriented strategy, are important success factors for new Stadtwerke.
\end{abstract}

Keywords: municipal utilities; Stadtwerke; energy transition; public value; performance measurement; performance indicators; resilience; digitalisation

\section{Introduction}

Mitigating climate change requires a fundamental and rapid transition in the way electricity is generated. While the global electricity sector with its conventional and climatedamaging power generation is dominated by large incumbent utility companies, local players, such as municipal utilities (e.g., German Stadtwerke), community and cooperative renewable energy (co)producers, are becoming increasingly important [1,2]. As the incumbents have historically been slow to embrace change [3], initiatives are increasingly taking place at the local level with the intention of accelerating the needed energy transition to mitigate climate change [4]. While the orientation of established players in the field of electricity generation is characterised by large and centralised technologies and trading structures, challengers focus on decentralised technologies and applications in their business strategies [3,5]. Energy companies that want to be successful in the long term must develop strategies to extend the value chain [6]. In Germany, an increasingly competitive market environment has emerged since the liberalisation of the electricity markets. For incumbents, adapting quickly to the associated challenges involves significant changes [7]. The European Commission's clean energy package [8] will further accelerate changes in the electricity market. Technical developments in decentralised renewables, sector coupling, storage technologies, electric mobility and heat pumps offer opportunities, especially for smaller players, to actively participate in the energy value chain [6,7]. Smart meters, energy management systems and new possibilities for communication and 
control technologies, which can also integrate small plants into energy markets, are the main contributors to this $[6,7,9]$. This means that energy companies must offer their customers energy services that lead to energy savings and the expansion of renewable energies. Many energy companies find it difficult to align their corporate strategies with these new challenges [6].

The traditional privilege enjoyed by incumbent electricity producers is challenged by new niche actors promoting energy transition from a decentralised level $[2,3,5]$. In this context, political struggles between competing interests are increasing. If the public sector wants to become economically active itself, this has to be justified very carefully. In Germany, public energy companies were founded primarily at the municipal level because municipal decision-makers wanted to have more influence on the energy industry [10]. It must be ensured at an early stage that the new activity does not lead to an excessive financial burden on public budgets. However, the nature of the changing political discourse and the consequences for political systems and their outcomes (e.g., more democratic policy processes, action on energy efficiency and climate protection) are poorly understood.

The establishment of municipal utilities has attracted a lot of attention for several years, not just in Germany [11,12]. A growing number of local governments, politicians and councillors have begun to view their appraisal of municipally controlled and operated utilities as a move towards generating benefits from municipal utilities. They came to realise that energy systems play an important role in the socioeconomic development of their respective communities [13]. In a bid to regain local responsibility for security of supply, many political initiatives have been undertaken in recent years to lead utility companies back into public ownership. The result is a renaissance of municipal utility companies and the municipal economy in Germany [10,14]. One hundred and fifty-two new local Stadtwerke were established in Germany within just eleven years between early 2005 and late 2016 [15,16]. The structure of the shareholders was usually designed in such a way that the municipality had a large influence on the company (Figure 1).

New German Stadtwerke according to the structure of ownership

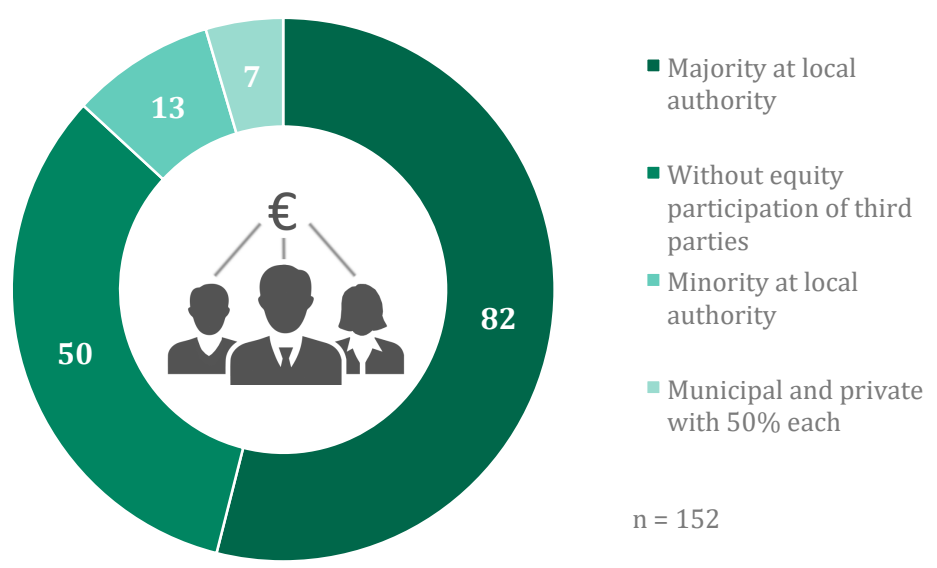

Figure 1. New municipal utilities in Germany and their ownership structure.

Municipal utilities are public companies that are majority-owned by one or more municipalities. They perform technical services and utilities, especially in the area of basic and general public services, with energy and water as part of their public mandate. In German-speaking countries, they are called Stadtwerke. In context with the growing importance of the energy transition and a worldwide trend towards re-municipalisation [11], the term "Stadtwerke" is also increasingly finding its way into other languages. Inspired by the experience of the German Stadtwerke and with European funding from the ELENA programme, Bristol designed an ambitious strategy to take back control of energy at the city level. In this context, it used the German term "Stadtwerke" [17]. This strategy led to the setting up of a municipal energy company, Bristol Energy, in 2016. In Japan, an as- 
sociation was even founded, which is called "Japan Stadtwerke Network". A number of decentralised companies have organised themselves in these, all of which have a special relationship to the municipalities and in which cities often also have a stake [12]. Since the beginning of the millennium, the phenomenon of "(re)municipalisation" marks a global trend for cities to take (sometimes formerly privatised) assets, infrastructure and services (back) into public ownership [14,18-20]. While in France and Latin America municipal involvement is particularly common in the water sector, Germany and the USA are focused on the energy sector $[10,11,15,18,21-24]$. After the Fukushima Daiichi nuclear disaster, there are increasing examples of municipal involvement in the establishment of energy utilities even in Japan $[11,25,26]$. In the UK, the motherland of privatisation, there are numerous local initiatives to set up energy companies. The University of Edinburgh prepared a first systematic survey of initiatives on "Local Authority Engagement in UK Energy Systems". According to this study, there was an increasing number of municipalities in the UK setting up municipal energy companies, which faced the political question of whether and how to start up a business [27]. In this context, the German Stadtwerke-model is perceived internationally as a role model for a community-based company that attains public value likewise with its tasks beyond commercial interests. The concept of public value has become increasingly widespread in different municipal fields and can be understood as a complementary partner of the shareholder value, driven by public interest. The public value illustrates the multidimensional objectives of municipal companies and the resulting benefits for the public good [28].

Questions in relation to the actions required to ensure success in the founding of a new business have already been discussed extensively and in detail in other studies over an extended period. However, the examination of the founding of a new Stadtwerke, in particular, has become an increased area of focus in recent years [23,29-31]. The typical characteristics of Stadtwerke, defined, in particular, through their economic and societal responsibilities, result in a different set of success factors than a "standard" new business. Consequently, a review of the success factors specific to Stadtwerke in the energy industry is warranted. On this basis, the authors of this paper conducted a research-based study with eleven newly founded Stadtwerke in Germany to determine these relevant success factors.

In recent years, there have been many research-based discussions in relation to Stadtwerke [32-35]. The underlying objective of these discussions is the rising number of newly established Stadtwerke. These utilities were and are being established by local councils as a vehicle for the re-municipalisation of energy supply with the aim of achieving the following goals [36]:

1. Democratisation of energy supply with a stronger focus on public value than traditional energy companies;

2. Achievement of environmental goals and implementation of the Energiewende at a local level;

3. Establishment and/or improvement in the local supply chain and the support of local market partners;

4. Increased awareness among the local community of the requirement for social responsibility in the provision of energy;

This list of goals highlights the difference in areas of strategic focus for Stadtwerke in comparison to other businesses. In particular, the focus of Stadtwerke tends to be wider than that of non-Stadtwerke entities. This is an element that needs to be considered in any discussion of success factors for Stadtwerke, as the answer to the question "what is success?" is often different compared to other entity types.

\section{Integration of our Study into the Theoretical Discourse}

Our explorative study, which by its nature was based on only a few cases of newly founded municipal utilities, was conducted against the background of theoretical discourse. First, the theoretical basis for the relevance of municipal utilities with regard to polycentric governance is considered and building on this, the theoretical basis with regard to the 
relevance of public value for municipal utilities is presented. In addition, a short excursion into the current discussion on key performance indicators (KPIs) is given.

\subsection{Theoretical Basis for the Relevance of Stadtwerke with Regard to Polycentric Governance}

Although the goals of Germany's energy transition are widely accepted, the specific route to get there is itself a matter of great controversy [37]. However, there is broad agreement that the local level must play an active role if the energy transition is to be a success. To implement the energy system transformation, municipal utilities are important cornerstones of polycentric governance in the multilevel political system. For a climateprotection motivated energy supply, it is obvious that the vast majority of measures here affect areas of competence of cities and municipalities. To focus on the local levels of government is important because this is where the implementation of national climate change policies and programs must occur [38].

It follows from this that energy system transformation cannot be left exclusively to the upstream levels of municipalities. The reason for this is that the municipalities, with their land-use planning and urban development statutes, provide the planning framework for the expansion of renewable energies on-site. The planning sovereignty of the municipalities also plays a major role in shaping the possible uses of decentralised combined heat and power plants within the framework of local grids for local and district heating. In addition, the potential for improving energy efficiency on the application side can primarily be tapped at the local level.

Polycentric governance for implementing the energy system transformation is characterised by principles for the efficient design of local institutions that can be applied by informed and committed citizens and authorities [39,40]. Self-organisation is an important advantage here, even if it is practically absent from classical economic theory [40]. Polycentric governance thus recognises the creative potential of non-governmental organisations, voluntary initiatives and organisations far beyond the market, provides more incentives and supports their commitment as a necessary and beneficial component of the overall process of energy transition [41,42]. This is shown by numerous experiences and practical examples, such as regional energy networks, bioenergy villages, $100 \%$ renewable energy communities, newly founded energy cooperatives, renewable energy plants with citizen financing, etc., which have significantly pushed the accelerated expansion of renewable energies in Germany.

Most energy transition projects are largely dependent on the competencies, responsibilities and opportunities of cities and municipalities. In the context of polycentric governance, municipal utilities are important actors for successful implementation and are suitable cooperation partners for citizen energy projects, energy cooperatives, voluntary initiatives and private energy projects with voluntary organisations [42]. This is possible because Stadtwerke have the necessary proximity to the citizens. They know the important local market partners, have a pronounced problem-solving competence and can, therefore, integrate the different creative potential in a municipality particularly well. This is a major difference compared to other energy companies.

\subsection{Theoretical Basis of the Relevance of Public Value for Stadtwerke}

The aim of a public value approach is to develop "a structure of practical reasoning for the orientation of managers of municipal utilities" [43]. The central criteria for the success of a publicly owned entity are twofold:

1. The achievement of a financially profitable business; and

2. The best possible fulfilment of a wider public purpose through the provision of public value.

The balance between the community and the elected officials who control the Stadtwerk is particularly important in this context. Looking specifically at the public value aspect of a Stadtwerk, we proposed a division into three main categories: 
1. There is a benefit for members of society arising from the provision of new and improved services;

2. There is a benefit to the wider community as a shareholder of a Stadtwerk whose services go beyond the supply of energy; and

3. There is an economic benefit for the wider region, which additionally provides important legitimacy for the community as a player in a competitive market.

In detail, there are numerous advantages that can be attributed to these three categories. The following graphic provides an overview in Figure 2.

\begin{tabular}{|c|c|c|}
\hline \multicolumn{3}{|c|}{ Public Value of Stadtwerke } \\
\hline $\begin{array}{l}\text { Value for the individual } \\
\text { citizen }\end{array}$ & $\begin{array}{l}\text { Value for the local } \\
\text { community }\end{array}$ & $\begin{array}{l}\text { Value for the regional } \\
\text { economy }\end{array}$ \\
\hline $\begin{array}{l}\text { Individual use of the products and } \\
\text { services of the Stadtwerk, for } \\
\text { example: } \\
\text { - Strong customer focus with local } \\
\text { customer service centre } \\
\text { - Tariff development which has a } \\
\text { focus on social responsibility } \\
\text { - Fair partner with increased trust in } \\
\text { the entity } \\
\text { - Quick support with individual } \\
\text { problems or queries } \\
\text { - Emphasis on quality in delivery of } \\
\text { services } \\
\text { - Compliance with Corporate Social } \\
\text { Responsibility (CSR) approach to } \\
\text { business } \\
\text { - Possibility for on-going } \\
\text { engagement in circumstances of } \\
\text { energy poverty }\end{array}$ & $\begin{array}{l}\text { Business use of products and } \\
\text { services ot the Stadtwerk and } \\
\text { cooperation an collaboration } \\
\text { opportunities, for example: } \\
\text { - Transfer of profits and tax } \\
\text { concessions to municipal budgets } \\
\text { an provision of localised } \\
\text { discounts for energy } \\
\text { - Sponsorship of local clubs and } \\
\text { initiatives } \\
\text { Cross-subsidisation of local } \\
\text { services (e.g. public transport, } \\
\text { swimming pools) } \\
\text { - Integration into the local „Agenda } \\
21 “ \text { plan } \\
\text { Local political influence and } \\
\text { citizen participation } \\
\text { Local problem solving } \\
\text { competencies developed } \\
\text { Synergies with other municipal } \\
\text { services (e.g. infrastructure } \\
\text { developments such as internet } \\
\text { services) } \\
\text { Partner for environment } \\
\text { protection } \\
\text { Support during natural disasters }\end{array}$ & $\begin{array}{l}\text { Economic benefits to the wider } \\
\text { region, for example: } \\
\text { - High regional economic value } \\
\text { - Increase in local employment } \\
\text { - Awarding of contracts to local and } \\
\text { regional suppliers } \\
\text { - Reliable partner for local } \\
\text { businesses } \\
\text { - Energy offers which allow for the } \\
\text { increased competitiveness of } \\
\text { local businesses } \\
\text { - Focus on long term customer and } \\
\text { business relationships with } \\
\text { service providers } \\
\text { - Support for local and regional } \\
\text { start-ups } \\
\text { - Design of digital structural } \\
\text { changes } \\
\text { - Formation of, or participation in, } \\
\text { local and regional business } \\
\text { networks }\end{array}$ \\
\hline
\end{tabular}

Figure 2. Public value of Stadtwerke Source: Own figure, based on [44].

As the public value of a Stadtwerk is considered a critical performance measure, it is important to investigate how the concept of public value can be measured and how it should be prioritised in comparison to other, more traditional performance measures.

\subsection{Theoretical basis of Key Performance Indicators}

The term KPI (Key Performance Indicator) refers to a company's key business indicators that are intended to reflect its performance. In this way, both the achievement of operational and strategic goals of a company can be checked. By doing this, the progress of projects, departments or even the entire company can be evaluated and controlled.

Depending on the focus of the observations, different types of KPIs can be used. Therefore, so-called E-KPIs (energy-related-KPI) can be a tool to monitor the energy management of a company or a municipal utility. Indicators like that can help to identify the weaknesses in the field of energy management and reveal possibilities to boost efficiency and effectiveness of energy consumption. Therefore, it is necessary to identify the relevant KPIs for the considered target, depending on the purpose of the investigation [45]. With the given objective of the energy transformation KPIs and especially energy-related-KPIs can be a supportive tool to reach those targets.

The central aims of E-KPIs are [46]:

1. Identification of energy drivers;

2. Transparent energy consumption 
3. Identification of interrelationships;

4. Define corrective actions;

5. Better communication.

KPIs play a particularly important role for newly founded companies, as the long-term survival of the business depends on their achievement. In our study, we examined the role of KPIs and other factors for newly founded municipal energy supply companies to be able to assess the success of the start-up.

\subsection{Conclusions from the Theoretical Reflection}

The performance measurement of a company is a comprehensive approach to plan and control its business activities systematically. A successful performance measurement system allows companies to formulate strategic objectives and to measure performance against these goals. The performance can either be measured with objective or subjective success measures. While objective performance measures refer to traditional economic KPIs (e.g., Earnings Before Interest and Taxes (EBIT), Earnings Before Interest, Taxes, Depreciation and Amortization (EBITDA), Return on Capital Employed (ROCE), Return on Investment (ROI), etc.), subjective success measures reflect the perception of top management on the performance of its company.

The common approach is the use of objective success measures to measure organisational performance. However, recent studies also show that subjective success measures can be used as a convenient alternative in case constant and reliable performance data are not available. As accounting data are rarely available for newly established public utilities, the author used a combined approach of objective and subjective success measures. General managers of these young companies were asked to state their satisfaction with selected economic performance variables.

Figure 3 summarises both dimensions which were used in the survey approach referring to economic and qualitative success. These dimensions have strong influences on the performance measurement of newly established public utilities. The preparation of the survey, including objective and subjective success measures, is described in the next chapter.

\begin{tabular}{l|l}
\hline Objective success measures & $\begin{array}{l}\text { Ibjective success measures } \\
\text { - Cost to serve }\end{array}$ Achievement of environmental goals and \\
implementation of local energy transition
\end{tabular}

Figure 3. Objective and subjective success measures.

\section{Methods}

The underlying methodology in our survey followed a classical approach to exploring and validating success factors. Acknowledging that Stadtwerke reflect a more heterogeneous character, success indicator may not be compared one by one based on financial Key Performance Indicators (KPIs), such as turnover or customer base. A similar challenge is given in research on entrepreneurship, where the approach on subjective performance measurement has been successfully applied. The main element of this methodology is not to measure the value of financial KPIs per se, but the perceived satisfaction with the KPI's 
fulfilment. In addition, measuring the importance of KPIs aims to reduce a potential bias and weight differences in applying the surveyed set of KPIs. This approach allows the application of indicators not only based on metric figures, such as earnings before interest and taxes (EBIT) or number of customers. More complex constructs, such as public value, reflecting performance can be captured and operationalised.

Our survey was conducted by means of an online survey. For this purpose, details of all 152 newly founded municipal utilities were first collected in an internet search. Only those companies that were also operationally active were to be surveyed. This did not apply to 30 companies, which were companies without staff. In these Stadtwerke, the operational activity was transferred to another company. It turned out that in such cases, the acquired electricity grid was often leased directly back to the former grid operator. All 122 operating companies were contacted several times and asked to participate. Eleven managing directors of newly founded municipal utilities finally took part in the survey. The participation rate of about $9 \%$ is in a typical range. We would have liked to have seen higher participation, but even repeated approaches did not lead to an increase in the rate.

The survey was structured as follows: After general information (e.g., location, year of foundation, number of employees, product portfolio, share of renewable energies), the newly founded municipal utilities were asked about various topics. In several parts, a total of 34 questions were asked about the strategic fields of action in terms of cooperation, resilience, digitalisation and social responsibility. The topics of resilience and digitalisation included questions on general aspects, but also on specific aspects that were categorised according to sales, generation, and grid operation. This categorisation was not necessary for the topics of cooperation and social responsibility. The questions contained statements about the energy sector in relation to the respective strategic field of action. The participants were asked to rate these statements on a 7-point Likert scale according to the degree of their agreement. The last section of the survey dealt with the performance measurement of the respective municipal utility. In a first step, the participants were asked to rate different economic measures of success-EBIT, public value, cost to serve, number of customers and sales growth-in terms of their importance for the internal determination of economic success. Following the same procedure, the managing directors were asked about the objectives of re-municipalisation, which were also evaluated in terms of importance and satisfaction. The focus of the objectives of re-municipalisation lies according to previous studies [10] in the implementation of the energy transition, the improvement in local value creation, the assumption of social responsibility in energy supply and the realisation of customer proximity and synergies with other (municipal) areas. Consequently, our survey asked about these aspects.

The utilised methodology essentially followed the approach of Dietz and later Annacker in relation to the study of success factors $[47,48]$. Possible areas of activity within different Stadtwerke were examined with the aim of assessing their influence on the success of an entity. The approach taken was designed to show the interrelationship between a particular action (e.g., Commitment to cooperation with a third party) and the success of the Stadtwerke.

The spheres of activity were assessed against a set of unique questions. The focus of these questions was the extent to which different possible courses of action were perceived by the Stadtwerke. The acceptance or rejection of these courses of action was placed on a 7-point Likert-Scale developed by Matell/Jacoby 1971 [49].

Through the assessment of newly established Stadtwerke, it was identified that the target goals could arise not only from economic aspects but also from a focus on public values (as described above). In this context, a selection of goals other than economic goals (namely goals in relation to re-municipalisation) was noted. On these grounds, questions concerning the following two goal types were asked: 
1. Economic Goals:

- $\quad$ EBIT

- Number of customers;

- Revenue growth;

- Cost to Serve;

- Public Value.

2. Goals in relation to re-municipalisation

- Environmental goals and the localised implementation of the energy transformation;

- Improvement in the local supply chain and stronger business relationships with local business partners;

- Recognition of social responsibility in the provision of energy services;

- Realisation of a closer relationship with customers and the local community;

- Realisation of synergies with other local businesses.

The assessment of the importance of these success factors was oriented towards a method of subjective performance measurement. The origin of this method lies in strategic business field research. The technique takes into account that companies or parts of companies are not arbitrarily comparable, nor do they have a clearly definable diversity relative to each other. Therefore, it cannot be assumed that KPIs, such as EBIT or customer numbers, will be interpreted with equal meaning (or equal importance) across different businesses.

It should additionally be noted that the concept of "success" is a complex construct that cannot be assessed through a single metric but is determined on the basis of a number of factors [50,51]. If one accepts the argument that Stadtwerke have a diverse nature in terms of size, turnover, number of customers, strategic orientation, etc., then it can be inferred that the same prerequisites exist as those designed to be assessed in the field of strategic business field research.

The method of subjective performance development was developed and published in a study by Gupta and Govindarajan in 1984 [52] and has already been successfully applied in the area of company formation [53-55]. As part of our study, the management of Stadtwerke was asked to assess, on a 7-point Likert Scale, how important particular success metrics were in the decision-making processes of the business. The satisfaction of business performance against these metrics was also asked for in our study, but this was not pursued further when assessing the outcomes of the thesis as tangible, successrelevant interdependencies on the basis of statistically significant results are not the focus of the method. This could, however, form the cornerstone of future research with clearly defined hypotheses and concrete analysis methods based on the explorative research undertaken here.

\section{Results of Subjective Performance Measurement}

The use of a subjective approach to performance measurement in our survey allowed for the utilisation of a well-established methodology for examining the investigation of start-up entities in other industries. Further, the approach allowed for an assessment of both traditional key performance indicators and additional determining factors in the measurement of business success.

The measurement of success can be seen to consist of two factors: economic success and additional success measures derived from the broader goals of the Stadtwerke. In this context, the results of our survey both confirmed the findings of previous studies $[34,56]$ while also indicating that these results alone were insufficient for measuring the success of a Stadtwerke. This is due to the fact that, upon the establishment of a Stadtwerk, traditional performance indicators are only one component of the strategic goals of the entity. 
In relation to economic performance indicators, the results of our survey indicated that customer numbers and revenue growth were considered by Stadtwerke as of equal importance to EBIT. This result is somewhat to be expected, as the growth in customer numbers (and the increase in revenue as a consequence of this customer growth) is a critical economic success factor.

Cost-to-Serve was, however, seen as playing a secondary role in comparison to customer numbers and revenue growth. This is perhaps unsurprising when one considers that for newly founded Stadtwerke, operational processes need to be first established and stabilised before being optimised for cost efficiencies at a later stage.

In addition to economic performance indicators, our survey also assessed the significance of public value. Although the concept of public value has no agreed definition and is, therefore, perceived (and measured) differently by different businesses, all Stadtwerke surveyed attached a similar level of importance in achieving public value indicators. This is somewhat surprising given that public value is rarely discussed and/or measured in annual or business reports. In addition, an assessment of public value in comparison to other market competitors is difficult due to the lack of a market-wide definition for the term. It should be noted, however, that individual elements that may form part of a wider definition of public value, such as impacts on local employment and use of a localised supply chain, can be measured as performance indicators and benchmarked against other Stadtwerke. An example of such an approach is the value creation report published by Stadtwerke Erkrath [57]. The results of the assessment are illustrated in Table 1 and Figure 4 .

Table 1. Assessment of importance of and satisfaction with performance indicators.

\begin{tabular}{|c|c|c|c|c|c|c|c|c|c|c|}
\hline & \multicolumn{5}{|c|}{ Importance of } & \multicolumn{5}{|c|}{ Satisfaction with } \\
\hline $\begin{array}{l}\text { Performance Indicators } \\
\text { Answer Options }\end{array}$ & 㫐 & 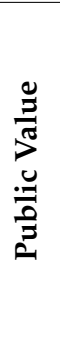 & 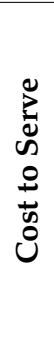 & 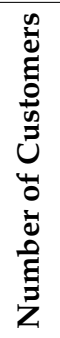 & 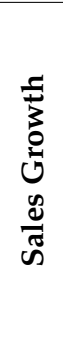 & 点 & 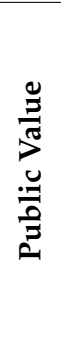 & 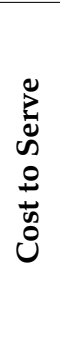 & 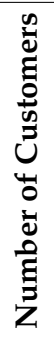 & 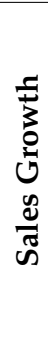 \\
\hline No Answer & 0 & 0 & 1 & 0 & 0 & 0 & 1 & 1 & 0 & 1 \\
\hline 7. Extremely important & 4 & 1 & 0 & 1 & 2 & 2 & 0 & 1 & 0 & 0 \\
\hline 6. Very important & 1 & 0 & 1 & 6 & 3 & 0 & 1 & 0 & 3 & 3 \\
\hline 5. Moderately important & 2 & 5 & 1 & 1 & 2 & 2 & 2 & 2 & 4 & 1 \\
\hline 4. Neutral & 2 & 1 & 2 & 1 & 3 & 4 & 2 & 2 & 0 & 1 \\
\hline 3. Slightly important & 1 & 0 & 2 & 2 & 1 & 1 & 1 & 3 & 3 & 5 \\
\hline 2. Low importance & 0 & 3 & 3 & 0 & 0 & 0 & 3 & 1 & 0 & 0 \\
\hline 1. Not at all important & 1 & 1 & 1 & 0 & 0 & 2 & 1 & 1 & 1 & 0 \\
\hline Sum & 11 & 11 & 11 & 11 & 11 & 11 & 11 & 11 & 11 & 11 \\
\hline $\begin{array}{l}\text { Variance Based on the } \\
\text { Sample (VAR.S) }\end{array}$ & 4 & 3 & 3 & 2 & 2 & 4 & 3 & 4 & 3 & 3 \\
\hline
\end{tabular}




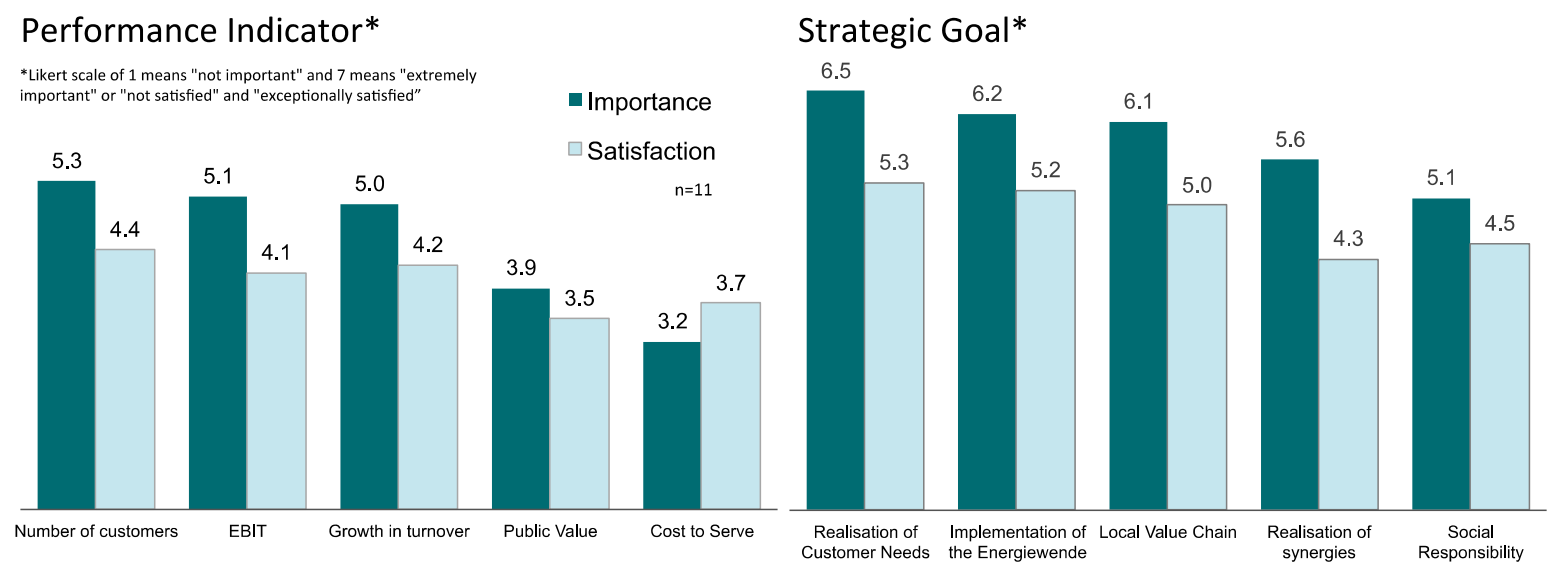

Figure 4. Assessment of the importance of strategic goals and performance indicators in the context of the establishment of a Stadtwerke.

Our survey results are presented in absolute values in the table above (Table 1). Overall, the variances in the answers were quite high (mostly 3 or 4). One reason for this could be that the companies were in different phases of economic success after their founding. The following chart shows the respective average values achieved for all performance indicators. Through the assessment of performance indicators and strategic goals, it is clear that the perceived importance of an indicator was often assessed higher than satisfaction with current performance against the indicator (see Figure 4). In addition, Figure 4 shows that strategic goals were considered more important than performance indicators. The strategic goals were shown to have the following prioritisation:

1. Realisation of a strong connection with customers and citizens;

2. Ecological goals and localised implementation of the energy transformation (Energiewende);

3. Improvement in the local economy and a stronger connection with local market partners;

4. Realisation of synergies with local industry;

5. Increased awareness of social responsibility in the context of energy supply.

Given that the strategic goals and performance indicators of a newly formed Stadtwerk were clearly established above, it should now be considered which actions may be undertaken to improve the likelihood of success as assessed against these goals and indicators.

\section{Discussion: Determination of Effective Actions}

Four elements were assessed through the survey to determine their relevance: Cooperation, Resilience, Digitalisation and Social Responsibility.

The results suggest that cooperation and collaboration were perceived as success factors for newly founded Stadtwerke. For example, strategic partnerships can assist in reducing problems with the development and organisation of the new business, while the awarding of contracts to local partners allows for the quick realisation of synergies with local industry and improvement in the local economy.

The development of a mission statement for the business before the commencement of operational activity can build the resilience of the new Stadtwerk [44]. The mission statement allows for a clear understanding within the business of the purpose of the entity and provides a cornerstone with which to anchor future strategy and business development. It is also notable that newly founded Stadtwerke were often opting for a business strategy based on delivery of high-quality products and services rather than a strategy based on beating the price of its competitors.

Further, our results indicated that Stadtwerke value the capacity to insulate themselves from and be resilient in the face of external market forces. Well over half of the survey participants were implementing a diversified product and service portfolio. In addition, 
three-quarters were continually investing in the development of new, or in the expansion of existing, renewable generation capacity, aiming to reduce the risks (e.g., price risks or availability risks) of being dependent on external sources for energy supply.

The following figure (Figure 5) presents a summary of our findings.

\begin{tabular}{|c|c|c|c|}
\hline $\begin{array}{l}\text { Cooperation } \\
\text { - Cooperations and } \\
\text { collaboration as a central } \\
\text { business strategy } \\
\text { - Local cooperation and } \\
\text { strategic partnerships } \\
\text { - Focus on cooperation } \\
\text { communities with less than } \\
25,000 \text { inhabitants } \\
\text { - Partnerships with } \\
\text { neighbouring Stadtwerke }\end{array}$ & $\begin{array}{l}\quad \text { Resilience } \\
\text { - Safeguarding a robust, stable } \\
\text { and reliable energy supply } \\
\text { delivery } \\
\text { - Diversification beyond nuclear } \\
\text { and fossil fuel resources } \\
\text { - Focus on renewable energy } \\
\text { - Focus on high quality products } \\
\text { and services } \\
\text { - High levels of innovation in } \\
\text { relation to local energy supply } \\
\text { - Modern distribution network } \\
\text { operation for electricity, gas } \\
\text { and/or heating } \\
\text { - Reduction of dependency on } \\
\text { energy imports }\end{array}$ & $\begin{array}{l}\text { Digitalisation } \\
\text { - Installation of smart meters and } \\
\text { - smart grids } \\
\text { - Implementation of gateways as } \\
\text { an open communication } \\
\text { platform } \\
\text { - Digitalisation of customer } \\
\text { communication and interaction } \\
\text { - Installation and integration of } \\
\text { digital products and services } \\
\text { - Development of Blockchain } \\
\text { solutions and peer-to-peer } \\
\text { business models }\end{array}$ & $\begin{array}{l}\text { Social Responsibility } \\
\text { - Acceptance of social and } \\
\text { community responsibilities - } \\
\text { Corporate Social Responsibility } \\
\text { (CSR) } \\
\text { - Orientation towards Public } \\
\text { Value } \\
\text { - Family-friendly workplaces } \\
\text { - Cross-subsidisation of public } \\
\text { transport, public facilities, etc. } \\
\text { - High-value apprenticeships and } \\
\text { further education opportunities } \\
\text { - Support for social and cultural } \\
\text { projects }\end{array}$ \\
\hline $\begin{array}{l}\text { Hypothesis: } \\
\text { The use of a cooperative and } \\
\text { collaborative approach in the } \\
\text { early phases of the creation } \\
\text { of a new Stadtwerk can have } \\
\text { a long-term positive benefit } \\
\text { on the economic success of } \\
\text { the business. }\end{array}$ & $\begin{array}{l}\text { Hypothesis: } \\
\text { Identifying resilience, } \\
\text { sustainability and the } \\
\text { environment as central values } \\
\text { of the Stadtwerk, and as key } \\
\text { elements of the mission } \\
\text { statement, supports the } \\
\text { achievement of the strategic } \\
\text { goals. }\end{array}$ & $\begin{array}{l}\text { Hypothesis: } \\
\text { Offering smart meters and } \\
\text { digital solutions can lead to } \\
\text { longer term business } \\
\text { development and } \\
\text { diversifikation. }\end{array}$ & $\begin{array}{l}\text { Hypothesis: } \\
\text { An increased awareness of } \\
\text { social responsibility can have a } \\
\text { positive effect on overall } \\
\text { business success. }\end{array}$ \\
\hline
\end{tabular}

Figure 5. Effective approaches and actions for newly-founded Stadtwerke.

The results of our survey suggested that digitalisation was perceived to have a relatively low level of importance. This is in part due to the fact that new Stadtwerke were often not active in all elements of the energy supply chain. For example, a smart-grid strategy is not important for a Stadtwerk that is not a grid operator.

Increased awareness of social responsibility in energy production and delivery is considered to play an important role in the success of a well-established Stadtwerke. This is reflected through the support of local events and community activities, the establishment of family-friendly workplace environments and the provision of high-quality apprenticeship and further education opportunities (see Figure 4). However, the implementation of such approaches by new Stadtwerke cannot be seen through the results of our survey. The reason for this is that achieving high levels of social responsibility requires a certain level of economic success, which does not yet exist for newly founded Stadtwerke.

The corona pandemic, which paralysed many areas of the economy, reveals the vulnerability and fragility of our civil society. The politically resolved lockdown with the closure of shops, schools and universities also gives people time to question previous developments. Many economists and political scientists see this as an opportunity for a fundamental rethink in society, politics, and business. This particularly applies to the entrepreneurial orientation of many commercial enterprises. Such voices were already audible before the corona crisis. Christian Felber et al. (2019), for example, complained that traditional corporate reporting does not sufficiently meet stakeholders' information needs [58]. Accordingly, the classic key indicators of corporate reporting are neither sufficient for assessing a company's past performance nor forecasting its future performance.

We also note that the significance of conventional turnover and profit ratios is limited. Especially in the case of municipal enterprises, the question arises whether a company serves the common good of a community, and this cannot be measured by conventional ratios alone. In our opinion, the importance of public welfare-oriented goals in the economy has become particularly clear in the wake of the corona pandemic. Moreover, an economy 
that focuses exclusively on growth and maximum profit has long since exceeded the limits of ecological sustainability. The threat of climate change, the extinction of species, the clearing of tropical rainforests and excessive mobility demands make it necessary to rethink the economy. Public companies can play an important pioneering role in this process. Our analysis showed that this is possible and purposeful. Existing concepts, such as that of the Economy for the Common Good (ECG), prove the practical benefit of a broader view of the economic efficiency of companies. The ECG aims to benefit all stakeholders in an organisation-employees, suppliers, customers, business partners, the local community and society at large. It does so with a Common Good Balance Sheet, which measures the impact the organisation has on these stakeholders.

\section{Conclusions}

The results of our survey indicate the following in the context of newly founded Stadtwerke:

1. The establishment of new Stadtwerke shows that many local politicians have recognised the positive potential of proactively implementing the Energiewende at a local level and that the establishment of a Stadtwerke is a key element in this implementation process.

2. The concept of public value is seen as having a high level of importance. Public value is generally considered to include the increased benefit for citizens and the delivery of increased value for the community and the wider regional economy.

3. Collaboration and cooperation with local and regional businesses is an important success factor for the establishment of a new Stadtwerke.

4. Resilience in the face of external market factors is seen as critical for newly established Stadtwerke. A well-thought-out mission statement, business strategies for intended products and services, as well as the development of energy provision capabilities are some of the factors required to build the necessary resilience within the new business.

The applied methodology of measuring the performance based on subjective evaluation fits the inhomogeneous characteristic of Stadtwerke. To analyse the external validity of the results more deeply, further stakeholders of the municipal utility can be taken into account, e.g., the supervisory board. In many cases, the mayor will also be the chairman of the supervisory board, who will assess the company from a different perspective. This may lead to the effect that, e.g., public value is higher ranked than strongly economicly driven KPIs, such as EBIT. In any case, this issue may be subject to further research activities. It would, therefore, be beneficial to expand the approach undertaken in this study to allow for a wider review of the interests of different stakeholders. This would provide a multidimensional approach to the measurement of the success of a newly founded Stadtwerke.

Our analysis showed that future evaluations of companies should increasingly focus on success factors based on the common good. According to Felber, public value aspects, common good goals and solidarity-based models of economic activity are suitable models for enabling important transformative impulses for the economy and society in the future $[58,59]$. In summary, we come to the following conclusion: municipal utilities oriented towards the common good and aiming for a climate-friendly and sustainable energy supply can also serve as role models for other sectors of the economy in the future. The applied method of subjective performance measurement is suitable for measuring conventional and common good-oriented success factors. This also applies to the method of subjective performance measurement, which focuses on the common good. Our exploratory study proved that more in-depth analyses are needed to measure the success factors of municipal utilities. In addition to the traditional KPIs, the aspects of the common good should be more strongly integrated into the political and economic evaluation of success for all companies. This would give the managing directors the opportunity to prove that their company serves society and not vice versa. 
Author Contributions: Conceptualisation, O.W.; Data curation, M.C.; Formal analysis, C.H.; Methodology, O.W., K.B., C.H.; Visualization, O.W., M.C., K.B.; Writing-original draft, O.W., K.B., C.H., M.C.. All authors have read and agreed to the published version of the manuscript.

Funding: This research received no external funding.

Institutional Review Board Statement: Not applicable.

Informed Consent Statement: Not applicable.

Data Availability Statement: The data presented in this study (SPSS data file) are available on request from the corresponding author. The data are not publicly available due to the size of the data.

Acknowledgments: We would like to thank the managing directors of newly founded Stadtwerke companies who took part in our survey. We would also like to thank our colleagues Callan Wisby and Lotte Nawothnig, who improved this text linguistically and Luisa Bischoff for her suggestions.

Conflicts of Interest: The authors declare no conflict of interest.

\section{References}

1. Frei, F.; Sinsel, S.R.; Hanafy, A.; Hoppmann, J. Leaders or Laggards? The Evolution of Electric Utilities' Business Portfolios during the Energy Transition. Energy Policy 2018, 120, 655-665. [CrossRef]

2. Brisbois, M.C. Powershifts: A Framework for Assessing the Growing Impact of Decentralized Ownership of Energy Transitions on Political Decision-Making. Energy Res. Soc. Sci. 2019, 50, 151-161. [CrossRef]

3. Berlo, K.; Wagner, O.; Heenen, M. The Incumbents' Conservation Strategies in the German Energy Regime as an Impediment to Re-Municipalization-An Analysis Guided by the Multi-Level Perspective. Sustainability 2017, 9, 53. [CrossRef]

4. Smink, M.M.; Hekkert, M.P.; Negro, S.O. Keeping Sustainable Innovation on a Leash? Exploring Incumbents' Institutional Strategies. Bus. Strategy Environ. 2015, 24, 86-101. [CrossRef]

5. Frey, U.J.; Wassermann, S.; Uhrig, D.M. Storage Technologies for the Electricity Transition: An Analysis of Actors, Actor Perspectives and Transition Pathways in Germany. Energies 2020, 14, 18. [CrossRef]

6. Wagner, O.; Adisorn, T.; Tholen, L.; Kiyar, D. Surviving the Energy Transition: Development of a Proposal for Evaluating Sustainable Business Models for Incumbents in Germany's Electricity Market. Energies 2020, 13, 730. [CrossRef]

7. Langer, L. An Optimal Peer-to-Peer Market Considering Modulating Heat Pumps and Photovoltaic Systems under the German Levy Regime. Energies 2020, 13, 5348. [CrossRef]

8. European Commission. Directorate-General for Energy Clean Energy for All Europeans; Publications Office: Luxembourg, 2019; ISBN 978-92-79-99835-5. [CrossRef]

9. Schletz, M.; Cardoso, A.; Dias, P.G.; Salomo, S. How Can Blockchain Technology Accelerate Energy Efficiency Interventions? A Use Case Comparison. Energies 2020, 13, 5869. [CrossRef]

10. Wagner, O.; Berlo, K. Remunicipalisation and Foundation of Municipal Utilities in the German Energy Sector: Details about Newly Established Enterprises. J. Sustain. Dev. Energy Water Environ. Syst. 2017, 5, 396-407. [CrossRef]

11. Kishimoto, S.; Petitjean, O.; Steinfort, L. Reclaiming Public Services: How Cities and Citizens Are Turning Back Privatisation; Bélanger, D.M., Doherty, A., Eds.; Transnational Institute (TNI): Amsterdam, The Netherlands, 2017; ISBN 978-90-70563-58-5.

12. Wagner, O.; Venjakob, M.; Schröder, J. The Growing Impact of Decentralised Actors in Power Generation: A Comparative Analysis of the Energy Transition in Germany and Japan. J. Sustain. Dev. Energy Water Environ. Syst. 2019. [CrossRef]

13. Kozioł, J.; Mendecka, B. Evaluation of Economic, Energy-Environmental and Sociological Effects of Substituting Non-Renewable Energy with Renewable Energy Sources. J. Sustain. Dev. Energy Water Environ. Syst. 2015, 3, 333-343. [CrossRef]

14. Becker, S.; Beveridge, R.; Naumann, M. Remunicipalization in German Cities: Contesting Neo-Liberalism and Reimagining Urban Governance? Space Polity 2015, 19, 76-90. [CrossRef]

15. Berlo, K.; Schäfer, D.; Wagner, O. Mitmischen Is Possible: Neugegründete Stadtwerke Nutzen Die Chancen Der Energiewende. Energ. Tagesfr. 2017, 67, 96-99.

16. Berlo, K.; Schäfer, D.; Wagner, O. Stadtwerke-Neugründungen in Deutschland: Eine Bilanz der Periode auslaufender Konzessionsverträge für örtliche Strom- und Gasverteilnetze; Planung neu denken online: New York, NY, USA, 2018.

17. Ruedinger, A. Local Energy Ownership in Europe an Exploratory Study of Local Public Initiatives in France, Germany and the United Kingdom; INIS: Vienna, Austria, 2017; p. 57.

18. Cumbers, A.; Becker, S. Making Sense of Remunicipalisation: Theoretical Reflections on and Political Possibilities from Germany's Rekommumalisierung Process. Camb. J. Reg. Econ. Soc. 2018, 11, 503-517. [CrossRef]

19. Berlo, K.; Templin, W.; Wagner, O. Remunicipalisation as an Instrument for Local Climate Strategies in Germany: The Conditions of the Legal Energy Framework as an Obstacle for the Local Energy Transition. Renew. Energy Law Policy Rev. $2016,7,113-121$.

20. Wollmann, H. Provision of Public Services in European Countries: Does the "Pendulum" Swing Back from Privatization to (Re-)Municipalization? Humboldt Universität zu Berlin: Berlin, Germany, 2013; p. 28.

21. Berlo, K.; Wagner, O. Stadtwerke-Neugründungen Und Rekommunalisierungen-Energieversorgung in Kommunaler Verantwortung; Wuppertal Institut: Wuppertal, Germany, 2013; pp. 1-99. 
22. American Public Power Association. Public Power for Your Community: Local Control. Local Priorities. A Stronger Local Economy; American Public Power Association: Arlington, TX, USA, 2016; p. 52.

23. Libbe, J. Transformation Städtischer Infrastruktur-Perspektiven Und Elemente Eines Kommunalen Transformationsmanagements Am Beispiel Energie. Ph.D. Thesis, Universität Leipzig, Saxony, Germany, 2014.

24. Hall, D.; Lobina, E.; Terhorst, P. Re-Municipalisation in the Early Twenty-First Century: Water in France and Energy in Germany. Int. Rev. Appl. Econ. 2013, 27, 193-214. [CrossRef]

25. Wagner, O.; Aydin, V.; Berlo, K.; Gericke, N.; Hennicke, P.; Venjakob, M. Shutattoberuke No Genjou to Shinsetsu No Nichidoku Hikaku: Kono Houkokusho Ha Doitsu Renpou Kankyou Shizen Hogo Genshiryoku Anzen Shou No Josei to Nihonkoku Seifu Kankyoushou No Kouen Ni Yori Shippitsu Sareta; Wuppertal Inst. für Klima, Umwelt, Energie: Wuppertal, Germany, 2018.

26. Berlo, K.; Wagner, O. Stichwort: Deutsche Stadtwerke als Vorbild für Japan. $e|m|$ w Energie. Markt. Wettbewerb. $2016,2,2$.

27. Webb, J.; Tingey, M.; Hawkey, D. What We Know about Local Authority Engagement in UK Energy Systems-Ambitions, Activities, Business Structures \& Ways Forward. School of Social and Political Science; University of Edinburgh: Edinburgh, Scotland, 2017.

28. Hoch, M. Citizen Value. Ph.D. Thesis, Technische Universität München, München, Germany, 2014. Available online: https: //mediatum.ub.tum.de/doc/1187216/1187216.pdf (accessed on 6 February 2021).

29. Weber, G.; Cabras, I.; Frahm, L.-G. De-Privatisation and Remunicipalisation of Urban Services through the Pendulum Swing: Evidence from Germany. J. Clean. Prod. 2019, 236, 117555. [CrossRef]

30. Berlo, K.; Wagner, O.; Merten, F.; Richter, N.; Thomas, S. Perspektiven dezentraler Infrastrukturen im Spannungsfeld von Wettbewerb, Klimaschutz und Qualität: Ergebnisse für die Energiewirtschaft; Wuppertal Inst. für Klima, Umwelt, Energie: Wuppertal, Germany, 2008; p. 442.

31. Richter, N.; Thomas, S. Perspektiven Dezentraler Infrastrukturen Im Spannungsfeld von Wettbewerb, Klimaschutz Und Qualität: Endbericht Der Forschungspartnerschaft INFRAFUTUR.; Lang: Hesse, Germany, 2009; Volume 16, ISBN 978-3-631-58274-9.

32. PricewaterhouseCoopers. Stadtwerke 2030-Herausforderungen der Energieversorgung in Kooperationen Meistern. 2018. Available online: https:/ / www.pwc.de/de/energiewirtschaft/stadtwerke-2030.pdf (accessed on 6 February 2021).

33. YourSales Stadtwerk Der Zukunft I-Update Perspektiven Kommunaler Energieversorgung 2020/2025; Stadtwerk der Zukunft: Sankt Gallen, Switzerland, 2011.

34. Pieper, F. Finanzwirtschaftliche Erfolgsanalyse deutscher Stadtwerke; Corporate finance and governance; PL Academic Research: Frankfurt am Main Bern Bruxelles, Belgium, 2016; ISBN 978-3-631-69927-0.

35. Ernst \& Young. Stadtwerkestudie 2017-Der Verteilnetzbetreiber Der Zukunft-Enabler Der Energiewende; Dortmund, Germany, 2017. Available online: https:/ / www.enerpedia.info/enerthek_util/cache/1505221576_ey-stadtwerkestudie-2017.pdf (accessed on 6 February 2021).

36. Berlo, K.; Herr, C.; Wagner, O.; Companie, M. Neugründung von Stadtwerken-worauf kommt es an? Energ. Tagesfr. 2019, 69, 99-102.

37. Gawel, E.; Lehmann, P.; Korte, K.; Strunz, S.; Bovet, J.; Köck, W.; Massier, P.; Löschel, A.; Schober, D.; Ohlhorst, D.; et al. The Future of the Energy Transition in Germany. Energy Sustain. Soc. 2014, 4, 15. [CrossRef]

38. Schreurs, M.A. From the Bottom Up: Local and Subnational Climate Change Politics. J. Environ. Dev. 2008, 17, 343-355. [CrossRef]

39. Ostrom, E. Polycentric Systems as One Approach for Solving Collective-Action Problems; Indiana University: School of Public \& Environmental Affairs: Bloomington, IN, USA, 2008; pp. 1-22.

40. Helfrich, S.; Stein, F. Was Sind Gemeingüter? Polit. Zeitgesch. 2011, 61, 9-15. [CrossRef]

41. Berlo, K.; Seifried, D. Nationale Prozessverantwortung-Regionale Selbstorganisation. In Gemeinschaftsprojekt Energiewende: Der Fahrplan zum Erfolg; Bartosch, U., Hennicke, P., Weiger, H., Eds.; Oekom-Verl.: München, Germany, 2014; pp. 74-84. ISBN 978-3-86581-668-9.

42. Berlo, K.; Hauptstock, D.; Hennicke, P.; Hey, C.; Jänicke, M.; Kopatz, M.; Leprich, U.; Linz, M.; Luhmann, H.-J.; Müller, M.; et al. The German Energiewende: A Transition towards an Efficient, Sufficient Green Energy Economy; Sonnenschein, J., Hennicke, P., Eds.; Internat. Inst. for Industrial Environmental Economics: Lund, Sweden, 2015; Available online: https: / / epub.wupperinst.org/ frontdoor/deliver/index/docId/6107/file/6107_Energiewende.pdf (accessed on 6 February 2021). ISBN 978-91-87357-18-3. [CrossRef]

43. Moore, M.H. Creating Public Value: Strategic Management in Government; Harvard University Press: Cambridge, MA, USA, 1995; ISBN 978-0-674-17557-0.

44. Berlo, K.; Herr, C.; Wagner, O.; Companie, M. Explorative Untersuchung zu Erfolgspotentialen bei neugegründeten Stadtwerken: Eine Sondierungsstudie zur kommunalen Energieversorgung; Ergebnisse einer Befragung bei neugegründeten Stadtwerken im Energiebereich; Wuppertal Inst. für Klima, Umwelt, Energie: Wuppertal, Germany, 2018; p. 48.

45. May, G.; Taisch, M.; Prabhu, V.V.; Barletta, I. Energy Related Key Performance Indicators-State of the Art, Gaps and Industrial Needs. In Advances in Production Management Systems. Sustainable Production and Service Supply Chains; Prabhu, V., Taisch, M., Kiritsis, D., Eds.; Springer: Berlin/Heidelberg, Germany, 2013; Volume 414, pp. 257-267, ISBN 978-3-642-41265-3.

46. May, G.; Barletta, I.; Stahl, B.; Taisch, M. Energy Management in Production: A Novel Method to Develop Key Performance Indicators for Improving Energy Efficiency. Appl. Energy 2015, 149, 46-61. [CrossRef]

47. Dietz, J.W. Gründung Innovativer Unternehmen. In Neue Betriebswirtschaftliche Forschung (NBF); Gabler Verlag: Wiesbaden, Germany, 1989. 
48. Annacker, D. Unbeobachtbare Einflussgrößen in Der Strategischen Erfolgsfaktorenforschung: Ein Kausalanalytischer Ansatz Auf Der Basis von Paneldaten; Deutscher Universitätsverlag: Wiesbaden, Germany, 2001.

49. Matell, M.S.; Jacoby, J. Is There an Optimal Number of Alternatives for Likert Scale Items? Study I: Reliability and Validity. Educ. Psychol. Meas. 1971, 31, 657-674. [CrossRef]

50. Kirchhoff, B.A. Organization Effectiveness Measurement and Policy Research. Acad. Manag. Rev. 1977, 2, 347-355. [CrossRef]

51. Venkatraman, N.; Ramanujam, V. Measurement of Business Economic Performance: An Examination of Method Convergence. J. Manag. 1987, 13, 109-122. [CrossRef]

52. Gupta, A.K.; Govindarajan, V. Business Unit Strategy, Managerial Characteristics, and Business Unit Effectiveness at Strategy Implementation. Acad. Manag. J. 1984, 27, 25-41. [CrossRef]

53. Herr, C. Nicht-Lineare Wirkungsbeziehungen von Erfolgsfaktoren Der Unternehmensgründung; Entrepreneurship; Deutscher Universitätsverlag: Wiesbaden, Germany, 2007.

54. Kimmeskamp, V. Konfigurationen von Messelogistikdienstleistern: Eine empirische Untersuchung des weltweiten Marktes; Logistik und Unternehmensführung; Kölner Wiss.-Verl: Köln, Germany, 2011; ISBN 978-3-942720-07-6.

55. Singh, S.; Darwish, T.K.; Potočnik, K. Measuring Organizational Performance: A Case for Subjective Measures: Measuring Organizational Performance. Br. J. Manag. 2016, 27, 214-224. [CrossRef]

56. Wildemann, H. Stadtwerke: Erfolgsfaktoren europäischer Infrastruktur- und Versorgungsdienstleister; 1. Aufl.; TCW, Transfer-Centrum: München, Germany, 2009; ISBN 978-3-937236-90-2.

57. Eduard Pestel Institut für Systemforschung e.V. Was Bleibt-Wertschöpfungsbericht Der Stadtwerke Erkrath; Stadtwerke Erkrath GmbH: Erkrath, Germany, 2016.

58. Felber, C.; Campos, V.; Sanchis, J.R. The Common Good Balance Sheet, an Adequate Tool to Capture Non-Financials? Sustainability 2019, 11, 3791. [CrossRef]

59. Felber, C. Die Gemeinwohl-Ökonomie: Das Wirtschaftsmodell der Zukunft; Nachdr Deuticke: Vienna, Austria, 2011; ISBN 978-3-552-06137-8. 